\title{
EFFECT OF APPLYING FINISHING PRODUCTS AND SANDING ON THE SURFACE OF MARUPA WOOD
}

\author{
Marcella Hermida de Paula ${ }^{1 \star}$, Robert Rossi Silva de Mesquita ${ }^{1}$, Mírian de Almeida Costa ${ }^{1}$, \\ Joaquim Carlos Gonçalez $z^{1}$, Rubén A. Ananías', Gèrard Janin ${ }^{3}$
}

\begin{abstract}
The effect of applying cetol and finishing varnish products and sanding on the surface roughness and colour of marupa (Simarouba amara) wood was evaluated. Three coats of each product were applied and two sandpaper grits were used, 280 and 320). The analyzes were performed on untreated samples and between each coat of products in order to analyze the effect of sanding, the products and the number of coats. According to colorimetry, the $\mathrm{L}^{*}$ value for the control treatment was 82,83 and the treatments reduced the $\mathrm{L}^{*}$ to 61,70 on average for the cetol treatment and 77,09 for the varnish treatment, showing that the cetol darkened the wood more than the varnish. The yellowish and reddish pigmentations became more intense according to the positive values of $\Delta \mathrm{a}^{*}$ and $\Delta \mathrm{b}^{*}$, especially after applying the cetol. The total colour variation $\Delta \mathrm{E}$ average was 40,79 for the cetol treatment and 9,83 for the varnish treatment, confirming a much more significant colour change in the cetol treatment. Sanding with different grits did not significantly alter the surface colour. The product application made the wood surface smoother, and was noticeable from the second coat. Sanding reduced roughness on the wood surface, but the finishing product was the largest source of variation.
\end{abstract}

Keywords: Colorimetry, roughness, sandpaper, Simarouba amara, varnish.

\section{INTRODUCTION}

Marupa wood is a pioneer species belonging to the Simaroubaceae family and is naturally distributed throughout the Amazon Region, the Central West and Southwest of Brazil. According to Cavalcante (2006), the wood of this species is light, beige-yellowish to cream, and presents a smooth texture when it receives a glossy finish; it is easily sawn, nailed, screwed and planed, in addition to receiving various finishes. It can be used in the furniture industry and in manufacturing toys, linings and boxes to store documents and other valuable materials. Souza et al. (1997) cited still other uses of marupa wood such as in civil and naval construction, bridges, etc., and it can be used in reforestation programs in regions of its natural distribution because it is a species with rapid growth.

However, this species still needs to be further studied, mainly when used in the furniture segment. In this case, the characteristics observed in the wood are the colour, the design, the roughness, the smell and its behavior before applying sandpaper and finishing products.

Colour can be a means of valuing a wood product, being used to aesthetically classify a wood as being acceptable or not through its comparison with other currently appreciated wood types in the market such as cherry, mahogany, and sucupira, among others (Camargos and Gonçalez 2001, Mori et al. 2004). This characteristic is a more significant factor in the wood market, often determining its final price, especially when it will be used as raw material for manufacturing furniture which requires product uniformity and reproducibility (Gonçalez 1993).

\footnotetext{
${ }^{1}$ Departamento de Engenharia Florestal, Faculdade de Tecnologia, Universidade de Brasília, Brasil.

${ }^{2}$ Departamento de Ingeniería en Maderas, Universidad del Bío-Bío, Concepción, Chile.

${ }^{3}$ INRA-Institute National de la Recherche Agronomique, Champenoux, France.

•Corresponding author: marcellahermida@hotmail.com

Received: 03.07.2018 Accepted: 12.10.2019
} 
The quality of a machined surface is also a determining factor for the various uses of wood. For example, those used to make furniture require high surface quality (Almeida et al. 2016), with this qualification being determined by direct means according to the ASTM D1666-87 (1995) which presents a subjective character, or indirectly through determining the $\mathrm{fz}$, which is the advance rate per saw tooth. Other ways of evaluating wood surface quality are found in the literature, with the roughness determination being the most highlighted form. Roughness is a quantitative parameter, making it possible to directly and objectively qualify the wood surface (Hazir and Koc 2018). According to Jakub and Martino (2005) and Aydin et al. (2013), studies on wood surface quality are extremely important for wood manufacturing processes, since it directly affects the finishing and glue line strength .

Moura and Hernandez (2006) describe sanding as the most used finishing method before applying the coating onto the wood (Koch 1964, Williams and Morris 1998). Its main objective is to produce surfaces without visible defects, as well as to standardize it (Koch 1964, Richter et al. 1995).

The properties and characteristics of sanded wood surfaces strongly differ from those obtained by planing. For example, sanding homogenizes the surface and reduces the influence of the anatomical structure on the roughness profile (Richter et al. 1995). Cell walls are compressed and lumens are clogged with dust during sanding (De Meijer et al. 1998). Sanded surfaces are also characterized by the presence of torn microfibrils and cell walls lifted by the abrasive action.

According to Kilic et al. (2006), the Brazilian furniture industry is growing but is not represented as a strong competitor in the world market due to the quality of machined surfaces, and even with having several methods to determine the quality of finished product surfaces such as roughness, there are still few records of the industry frequently using these methods.

The use of finishing products is essential to preserve a piece of wood as much as possible when in use. Although there are several products available for this purpose such as varnishes, paints and stains, little is known about the effect of these applications on wood colour and roughness. Natural semi-gloss cetol is a product based on special alkyd type resins, microbicide, transparent UV absorbers, functional mineral fillers, turpentine and additives. Maritime varnish is an alkyd polymer in oils dissolved in solvents, and according to the manufacturer's manual it is used as a protective film or decorative coating.

The objective of this work was to evaluate the behavior of the colour and surface roughness of marupa wood treated with cetol and varnish finishing products, in addition to sanding with 280 and 320 grit sandpaper between each product coat in order to analyze the effect of sandpaper, finishing products and the number of applications.

\section{MATERIALS AND METHODS}

This study was carried out at the Wood Technology Laboratory of the Forestry Engineering Department of the University of Brasília - UnB.

The marupa (Simarouba amara Aubl) wood was acquired in the form of boards from a local store in Brasília - DF, and sawn into samples of $40 \times 80 \times 10 \mathrm{~mm}$ of width, length and thickness, respectively, at the Laboratory of Forest Products (Serviço Florestal Brasileiro/MAPA).

A total of 13 treatments with 5 samples per treatment were analyzed, being divided into 4 groups as described in Table 1. Sandpaper grits 280 and 320 along with varnish and cetol finishing products were evaluated. The already planed boards had well-finished surfaces, being complemented with finishing sanding strips in the finishing process. The samples were initially sanded by 4 sanding cycles, each corresponding to one round and back of the sandpaper on the sample's surface, and then three coats of varnish or cetol were applied with a brush onto each sample; 4 sanding cycles were also applied on the sample surface between the first and second coating.

Samples were analyzed for colour and surface roughness between each coating, meaning before sanding and after product reapplication to analyze the effect of products and sanding on these properties and also the 
difference between the number of product applications.

Table 1: Treatment description.

\begin{tabular}{|c|c|c|}
\hline Group & Treatment & Description \\
\hline No treatment & Control & $\begin{array}{l}\text { Control sample not sanded and not treated } \\
\text { with product }\end{array}$ \\
\hline \multirow{3}{*}{$\begin{array}{l}\text { 280-grit sandpaper } \\
\text { and cetol }\end{array}$} & 280 cetol 1 & $\begin{array}{l}\text { Samples sanded with } 280 \text {-grit sandpaper and } 1 \\
\text { coat of cetol applied }\end{array}$ \\
\hline & 280 cetol 2 & $\begin{array}{l}\text { Samples sanded with } 280 \text {-grit sandpaper and } 2 \\
\text { coats of cetol applied }\end{array}$ \\
\hline & 280 cetol 3 & $\begin{array}{l}\text { Samples sanded with } 280 \text {-grit sandpaper and } 3 \\
\text { coats of cetol applied }\end{array}$ \\
\hline \multirow{3}{*}{$\begin{array}{l}\text { 280-grit sandpaper } \\
\text { and varnish }\end{array}$} & 280 varnish 1 & $\begin{array}{c}\text { Samples sanded with } 280 \text {-grit sandpaper and } 1 \\
\text { coat of varnish applied }\end{array}$ \\
\hline & 280 varnish 2 & $\begin{array}{c}\text { Samples sanded with } 280 \text {-grit sandpaper and } 2 \\
\text { coats of varnish applied }\end{array}$ \\
\hline & 280 varnish 3 & $\begin{array}{c}\text { Samples sanded with } 280 \text {-grit sandpaper and } 3 \\
\text { coats of varnish applied }\end{array}$ \\
\hline \multirow{3}{*}{$\begin{array}{l}\text { 320-grit sandpaper } \\
\text { and cetol }\end{array}$} & 320 cetol 1 & $\begin{array}{c}\text { Samples sanded with } 320 \text {-grit sandpaper and } 1 \\
\text { coat of cetol applied }\end{array}$ \\
\hline & 320 cetol 2 & $\begin{array}{l}\text { Samples sanded with } 320 \text {-grit sandpaper and } 2 \\
\text { coats of cetol applied }\end{array}$ \\
\hline & 320 cetol 3 & $\begin{array}{l}\text { Samples sanded with } 320 \text {-grit sandpaper and } 3 \\
\text { coats of cetol applied }\end{array}$ \\
\hline \multirow{3}{*}{$\begin{array}{l}\text { 320-grit sandpaper } \\
\text { and varnish }\end{array}$} & 320 varnish 1 & $\begin{array}{c}\text { Samples sanded with } 320 \text {-grit sandpaper and } 1 \\
\text { coat of varnish applied }\end{array}$ \\
\hline & 320 varnish 2 & $\begin{array}{c}\text { Samples sanded with } 320 \text {-grit sandpaper and } 2 \\
\text { coats of varnish applied }\end{array}$ \\
\hline & 320 varnish 3 & $\begin{array}{c}\text { Samples sanded with } 320 \text {-grit sandpaper and } 3 \\
\text { coats of varnish applied }\end{array}$ \\
\hline
\end{tabular}

\section{Colorimetry}

Colour analysis was performed using spectrophotometry with the diffuse reflectance technique in the visible electromagnetic spectrum range, according to the methodology of Gonçalez (1993).

A total of 10 readings were performed on the tangential face of each sample for each treatment using an X-Rite Colour Eye XTH spectrophotometer with $3 \mathrm{~nm}$ resolution, equipped with diffractive reflectance integrating sphere, D65 illuminant, an observation angle of $10^{\circ}$, room temperature, and coupled to a microcomputer. The colorimetric parameters of the CIELAB 1976 system determined were: lightness represented by L*, red-green and yellow-blue colours represented by coordinates $\mathrm{a}^{*}$ and $\mathrm{b}^{*}$ respectively, saturation represented by $\mathrm{C}$ and hue angle, represented by $\mathrm{h}$ *. The saturation and the hue angle were determined from Equation 1 and Equation 2, respectively:

$$
\begin{aligned}
& C=\frac{\left(a^{* 2}+b^{* 2}\right)}{2} \\
& h^{*}=\tan ^{-1} \frac{b^{*}}{a^{*}}
\end{aligned}
$$

In which:

C - saturation

a* - red-green axis tint

b* - yellow-blue axis tint

h* - hue angle 
In order to determine the changes in the wood colour after each treatment, the total colour variation $\Delta \mathrm{E}^{*}$ was used in accordance with ASTM D2244 (2009) according to Equation 3, which considers the differences in the chromatic and luminosity coordinates, providing a broader view of the change in wood colour. The use of this parameter has been adopted by several authors such Kerber et al. (2016), Freitas et al. (2016), Mendes et al. (2016) and Mesquita et al. (2017).

$$
\Delta E^{*}=\sqrt{\Delta L^{* 2}+\Delta a^{* 2}+\Delta b^{* 2}}
$$

In which:

$\Delta \mathrm{E}^{*}$ - Total colour change between treatments

$\Delta \mathrm{L}^{*}$ - Variation of luminosity between treatments

$\Delta \mathrm{a}^{*}$ - Variation of the chromatic coordinates

$\Delta \mathrm{b} *$ - Variation of the chromatic coordinates

Table 2 was used to classify the colour change based on the levels of visual perception, as proposed by Hikita et al. (2001).

Table 2: Classification of total wood colour variation (Hikita et al. 2001).

\begin{tabular}{|c|c|}
\hline Total Colour Change $\left(\Delta \mathbf{E}^{*}\right)$ & Classification \\
\hline $0,0-0,5$ & Negligible \\
\hline $0,5-1,5$ & Slightly perceptible \\
\hline $1,5-3,0$ & Notable \\
\hline $3,0-6,0$ & Appreciable \\
\hline $6,0-12,0$ & Very appreciable \\
\hline
\end{tabular}

\section{Surface roughness}

The surface roughness of the samples was determined using Surftest SJ - 400 (Mitutoyo) equipment, according to the norm JIS B 0601 (2001), with a cut-off of $0,8 \mathrm{~mm}$ and an evaluation path of $8 \mathrm{~mm}$. The measurements were performed in 3 different equidistant positions within each sample in the direction perpendicular to the fibers. The equipment device measures the surface roughness, obtaining the peak-valley profile of the surface by moving the needle of the scanning tip up and down on the sample surface. The center line between the valleys and profile peaks reflects the average roughness $(\mathrm{Ra})$ in $\mu \mathrm{m}$, which is the parameter evaluated for roughness in this study.

\section{Statistical analysis}

Mean colorimetric and roughness parameters were submitted to analysis of variance with the help of the ASSISTAT 7.7 program in order to verify the existence of statistical difference between the treatments. The Tukey test was applied at 5\% significance for the values that differed statistically, meaning when the F-value was significant $(\alpha=0,05)$. 


\section{RESULTS AND DISCUSSION}

\section{Colorimetry}

Table 3 shows the mean values of the colorimetric parameters of the untreated marupa wood treated according to the products and sandpaper.

Table 3: Mean values of the colorimetric parameters of the treated and untreated marupa wood surface.

\begin{tabular}{|c|c|c|c|c|c|c|}
\hline & Coats & $\mathbf{L}^{*}$ & $a^{*}$ & b* $^{*}$ & $\mathrm{C}$ & h* \\
\hline \multirow{2}{*}{ Control } & & $82,83 \mathrm{a}$ & $3,51 \mathrm{e}$ & $22,72 \mathrm{e}$ & $22,99 \mathrm{e}$ & $81,23 \mathrm{a}$ \\
\hline & & $(1,25)$ & $(0,33)$ & $(0,66)$ & $(0,70)$ & $(0,58)$ \\
\hline \multirow{6}{*}{ Cetol 280} & \multirow{2}{*}{1} & $66,09 \mathrm{c}$ & $15,72 \mathrm{c}$ & $48,42 \mathrm{~b}$ & $50,93 \mathrm{~b}$ & $72,04 \mathrm{~b}$ \\
\hline & & $(1,56)$ & $(0,73)$ & $(0,83)$ & $(0,74)$ & $(0,95)$ \\
\hline & \multirow{2}{*}{2} & $61,19 \mathrm{~d}$ & $22,84 \mathrm{~b}$ & $54,92 \mathrm{a}$ & $59,51 \mathrm{a}$ & $67,40 \mathrm{c}$ \\
\hline & & $(1,49)$ & $(1,39)$ & $(1,70)$ & $(1,77)$ & $(1,28)$ \\
\hline & \multirow{2}{*}{3} & $57,16 \mathrm{e}$ & $26,38 \mathrm{a}$ & $52,85 \mathrm{a}$ & $59,09 \mathrm{a}$ & $63,43 \mathrm{~d}$ \\
\hline & & $(1,27)$ & $(0,77)$ & $(2,02)$ & $(1,89)$ & $(1,04)$ \\
\hline \multirow{6}{*}{ Cetol 320} & \multirow{2}{*}{1} & $66,04 \mathrm{c}$ & $16,16 \mathrm{c}$ & $48,81 \mathrm{~b}$ & $51,42 \mathrm{~b}$ & $71,70 \mathrm{~b}$ \\
\hline & & $(0,78)$ & $(0,52)$ & $(0,86)$ & $(0,95)$ & $(0,34)$ \\
\hline & \multirow{2}{*}{2} & $61,73 \mathrm{~d}$ & $22,72 \mathrm{~b}$ & $55,38 \mathrm{a}$ & 59,87 a & $67,68 \mathrm{c}$ \\
\hline & & $(1,26)$ & $(0,90)$ & $(0,79)$ & $(0,72)$ & $(0,93)$ \\
\hline & \multirow{2}{*}{3} & $58,02 \mathrm{e}$ & $26,02 \mathrm{a}$ & $53,84 \mathrm{a}$ & $59,82 \mathrm{a}$ & $64,19 \mathrm{~d}$ \\
\hline & & $(1,27)$ & $(0,85)$ & $(1,28)$ & $(0,94)$ & $(1,16)$ \\
\hline \multirow{6}{*}{$\begin{array}{c}\text { Varnish } \\
280\end{array}$} & \multirow{2}{*}{1} & $77,13 \mathrm{~b}$ & $4,55 \mathrm{de}$ & $28,74 \mathrm{~d}$ & $29,10 \mathrm{~d}$ & $81,00 \mathrm{a}$ \\
\hline & & $(0,91)$ & $(0,28)$ & $(2,17)$ & $(2,19)$ & $(0,25)$ \\
\hline & \multirow{2}{*}{2} & $77,44 \mathrm{~b}$ & $4,92 \mathrm{de}$ & $29,76 \mathrm{~cd}$ & $30,17 \mathrm{~cd}$ & $80,64 \mathrm{a}$ \\
\hline & & $(1,23)$ & $(0,43)$ & $(2,15)$ & $(2,18)$ & $(0,32)$ \\
\hline & \multirow{2}{*}{3} & $77,02 \mathrm{~b}$ & $5,02 \mathrm{~d}$ & $30,00 \mathrm{~cd}$ & $30,42 \mathrm{~cd}$ & $80,51 \mathrm{a}$ \\
\hline & & $(0,52)$ & $(0,38)$ & $(2,31)$ & $(2,33)$ & $(0,19)$ \\
\hline \multirow{6}{*}{$\begin{array}{c}\text { Varnish } \\
320\end{array}$} & \multirow{2}{*}{1} & $77,73 \mathrm{~b}$ & $5,19 \mathrm{~d}$ & $30,80 \mathrm{~cd}$ & $31,24 \mathrm{~cd}$ & $80,45 \mathrm{a}$ \\
\hline & & $(0,72)$ & $(0,36)$ & $(0,39)$ & $(0,39)$ & $(0,66)$ \\
\hline & \multirow{2}{*}{2} & $76,45 \mathrm{~b}$ & $5,49 \mathrm{~d}$ & $31,70 \mathrm{~cd}$ & $32,17 \mathrm{~cd}$ & $80,18 \mathrm{a}$ \\
\hline & & $(0,57)$ & $(0,44)$ & $(0,38)$ & $(0,40)$ & $(0,76)$ \\
\hline & \multirow[b]{2}{*}{3} & $76,79 \mathrm{~b}$ & $5,57 \mathrm{~d}$ & $31,94 \mathrm{c}$ & $32,43 \mathrm{c}$ & $80,11 \mathrm{a}$ \\
\hline & & $(0,58)$ & $(0,39)$ & $(0,54)$ & $(0,52)$ & $(0,72)$ \\
\hline
\end{tabular}

$\mathrm{L}^{*}=$ lightness; $\mathrm{a}^{*}=$ red-green axis tints; $\mathrm{b}^{*}=$ yellow-blue axis tints; $\mathrm{C}=$ saturation; $\mathrm{h}^{*}=$ hue angle. Values marked with different letters within the same column differ at the $5 \%$ significance level by the Tukey test. The values in parentheses refer to the standard deviation.

The light colour of marupa wood is explained by the high $\mathrm{L}^{*}$ values of 82,83 the marked presence of yellow pigment $\left(b^{*} 22,72\right)$ and low presence of the red pigment $\left(a^{*} 3,51\right)$. Similar behavior of $L^{*}$ variation in relation to yellow and red pigments was correlated in a work by Cisneros et al. (2019) in analyzing Prosopis alba wood. The high $\mathrm{h}^{*}$ value of 81,23 positions the colour of this wood near the $\mathrm{b}^{*}$ axis, confirming the great influence of the $b^{*}$ coordinate on the colour characterization of the studied wood. Similar results were observed by Costa (2009), Arruda et al. (2011) and Melo et al. (2013) in relation to marupa wood colour before the treatments.

The wood colour is derived from the chemical composition of the extractive substances present in the xylem (tannins, phenols, flavonoids, stilbenes, quinones and others) which give different colours to the wood. Therefore, the combination between the high values observed for the $\mathrm{L}^{*}$ coordinate and the low values observed for the $\mathrm{a}^{*}$ coordinate may still be indicative of the low percentage of extractives present in the wood.

The wood surface became darker upon receiving the two finishing products, with the cetol darkening it more than the varnish. Regarding the cetol, the application of successive coats further darkened the wood, with differences between each coat. After the application of the first coat, $\mathrm{L}^{*}$ showed a value of 66,09 after the 280 -grit sandpaper and 66,04 after the 320-grit sandpaper; after the second coat, L* was 61,19 after the 280 grit sandpaper and 61,73 after the 320-grit sandpaper; finally, L* showed a value of 57,16 after the 280-grit sandpaper and 58,02 after the 320-grit sandpaper after three coats, which did not happen for the varnish, as it maintained its lightness without a significant change between the coats, with $L^{*}$ varying around 77. 
According to Camargos and Gonçalez (2001), wood is considered dark if the $\mathrm{L}^{*}$ value is less than or equal to 56 . The increase in the red pigmentation represented by a* coordinate also helps to explain the wood darkening after applying the finish, especially for the cetol. The increase in the a* parameter mainly after 3 coats of the product was notable, and was less noticeable after applying the varnish. The $\mathrm{h}^{*}$ parameter confirmed the increase of $\mathrm{a}^{*}$, with the decrease of its values showing the colour approximation in the $\mathrm{a}^{*}$ green-red coordinate axis, as can be seen for the cetol.

The $b^{*}$ parameter presented a positive value corresponding to yellow colour and had a high increase after applying the two products. According to Gonçalez et al. (2010), it is probable that these products have yellow pigment in their composition or that their interaction with the wood creates this pigment. The author observed the same behavior found in this study; a significant increase of the $b^{*}$ parameter for freijo wood when varnish and stain were applied.

As the $\mathrm{L}^{*}$ parameter is influenced by the $\mathrm{a}^{*}$ and $\mathrm{b}^{*}$ chromatic coordinates which characterize wood coloration, it was observed that the marupa wood colours became more intense and saturated due to the increase in the yellow pigmentation $\left(b^{*}\right)$ and chromaticity $(C)$ after treatments.

The $\Delta \mathrm{L}^{*}, \Delta \mathrm{a}^{*}, \Delta \mathrm{b}^{*}$ and $\Delta \mathrm{E}$ values are presented in Table 4 . Attention should be paid to the $(+)$ and $(-)$ signals which represent the increase in brightness $\left(+\Delta \mathrm{L}^{*}\right)$, the reduction in brightness $\left(-\Delta \mathrm{L}^{*}\right)$, more pronounced manifestation of green $\left(-\Delta \mathrm{a}^{*}\right)$ and blue $\left(-\Delta \mathrm{b}^{*}\right)$, increase in red colour $\left(+\Delta \mathrm{a}^{*}\right)$ and increase in yellow colour $\left(+\Delta b^{*}\right)$.

Table 4: Colour change between varnish and cetol treatments and 280 and 320-grit sandpaper in marupa wood.

\begin{tabular}{|c|c|c|c|c|c|}
\hline \multirow{2}{*}{ Treatment } & Coats & $\boldsymbol{\Delta} \mathbf{L}^{*}$ & $\mathbf{\Delta} \mathbf{a}^{*}$ & $\mathbf{\Delta} \mathbf{b}^{*}$ & $\boldsymbol{\Delta} \mathbf{E}^{*}$ \\
\hline \multirow{3}{*}{ Cetol 280 } & 1 & $-16,73$ & 12,21 & 25,71 & 33,02 \\
\cline { 2 - 6 } & 2 & $-21,64$ & 19,33 & 32,21 & 43,35 \\
\cline { 2 - 6 } & 3 & $-25,67$ & 22,88 & 30,14 & 45,72 \\
\hline \multirow{3}{*}{ Cetol 320 } & 1 & $-16,78$ & 12,65 & 26,10 & 33,51 \\
\cline { 2 - 6 } & 2 & $-21,10$ & 19,21 & 32,67 & 43,38 \\
\cline { 2 - 6 } & 3 & $-24,81$ & 22,51 & 31,13 & 45,73 \\
\hline \multirow{3}{*}{ Varnish 280 } & 1 & $-5,69$ & 1,05 & 6,03 & 8,36 \\
\cline { 2 - 6 } & 2 & $-5,39$ & 1,41 & 7,05 & 8,98 \\
\hline \multirow{3}{*}{ Varnish 320 } & 3 & $-5,81$ & 1,51 & 7,29 & 9,44 \\
\cline { 2 - 6 } & 2 & $-5,10$ & 1,68 & 8,08 & 9,71 \\
\cline { 2 - 6 } & 3 & $-6,38$ & 1,98 & 8,98 & 11,20 \\
\hline
\end{tabular}

$\Delta \mathrm{E}^{*}=$ total colour change between treatments; $\Delta \mathrm{L}^{*}=$ luminosity variation between treatments; $\Delta \mathrm{a}^{*}$ and $\Delta \mathrm{b}^{*}=$ variation of chromatic coordinates.

It was feasible to observe that the marupa darkened after applying the products, but this darkening was more intense after applying three cetol coats and the 280-grit sandpaper was used, as indicated by $\Delta \mathrm{L}^{*}$ equal to $-25,67$ when compared to $\Delta \mathrm{L}^{*}$ of $-6,04$ after applying three coats of varnish and using the 320-grit sandpaper. The yellowish and reddish pigmentations became more intense, especially after the cetol, according to the positive values of $\Delta \mathrm{a}^{*}$ and $\Delta \mathrm{b}^{*}$. The total colour variation $\Delta \mathrm{E}^{*}$ was higher after applying cetol. In observing Table 2 , the total colour variation was classified as very appreciable after applying the two products, as suggested by Hikita et al. (2001). Sanding with different grit sizes did not significantly alter the surface colour. 


\section{Surface roughness}

The average surface roughness $(\mathrm{Ra})$ of the samples between each coat of varnish and cetol is shown in Table 5.

It was observed that the first coat of the finishing product did not affect the sample roughness in all treatments, except the treatment with varnish and 280 -grit sandpaper, thus not presenting a statistically significant difference between the control and the first coat.

Table 5: Average marupa wood surface roughness submitted to different finishing treatments.

\begin{tabular}{|c|c|c|}
\hline Treatment & Coats & Roughness $(\boldsymbol{\mu m})$ \\
\hline Control & 0 & $6,30 \mathrm{a}$ \\
\hline \multirow{3}{*}{ Cetol 280 } & 1 & $5,46 \mathrm{a}$ \\
\cline { 2 - 3 } & 2 & $2,76 \mathrm{~b}$ \\
\cline { 2 - 3 } & 3 & $1,09 \mathrm{~b}$ \\
\hline \multirow{3}{*}{ Cetol 320 } & 1 & $5,70 \mathrm{a}$ \\
\cline { 2 - 3 } & 2 & $2,54 \mathrm{~b}$ \\
\cline { 2 - 3 } & 3 & $1,51 \mathrm{~b}$ \\
\hline \multirow{3}{*}{ Varnish 280 } & 1 & $7,07 \mathrm{a}$ \\
\cline { 2 - 3 } & 2 & $6,03 \mathrm{a}$ \\
\cline { 2 - 3 } & 3 & $4,42 \mathrm{a}$ \\
\hline \multirow{3}{*}{ Varnish 320 } & 1 & $6,37 \mathrm{a}$ \\
\cline { 2 - 3 } & 2 & $5,04 \mathrm{~b}$ \\
\cline { 2 - 3 } & 3 & $3,90 \mathrm{~b}$ \\
\hline
\end{tabular}

Values indicated with different letters within each treatment and compared to the control differ at the level of 5\% significance by the Tukey test.

There was a significant reduction in the roughness from the second coat in all treatments, except for the treatment with varnish and 280-grit sandpaper, with the most prominent reduction occurring in samples treated with cetol. In this treatment, the samples that suffered the most reduced roughness were sanded with 280 -grit sandpaper $(1,09 \mu \mathrm{m})$, followed by 320 -grit sandpaper $(1,51 \mu \mathrm{m})$, when compared to the control $(6,30 \mu \mathrm{m})$. The samples treated with varnish and 280 and 320-grit obtained a roughness of 4,42 $\mu \mathrm{m}$ and 3,90 $\mu \mathrm{m}$, respectively, indicating that the cetol product generates a smoother surface when compared to the varnish.

In relation to the samples treated with cetol, those that were sanded presented statistically different values from those which were untreated. However, sandpaper grits are statistically the same when compared to each other. The samples treated with varnish and sanded and those which were untreated did not present statistical differences. Works where sanded woods with higher grit number presented less roughness are found in the literature (Aslan et al. 2008, Hiziroglu et al. 2014, Imirzi et al. 2014, Laina et al. 2017). For this study, even though there is confirmation in absolute numbers of the sanding with higher grit presenting less roughness, it was not statistically proven because the 280 and 320-grit sandpapers did not show differences between them from the second product coating. Despite this non-statistical difference, in practice it was observed that the samples sanded with higher grit and having three product coatings presented smoother and better finished surfaces. It is crucial to verify whether the increase in cost by adding one more sanding plus one coat of the product in the process will be aggregated in the final quality of the produced pieces, thus reflecting in more significant market values.

Figure 1 shows the roughness profile of the control and the samples treated with three coats of varnish and cetol for each type of sandpaper. 


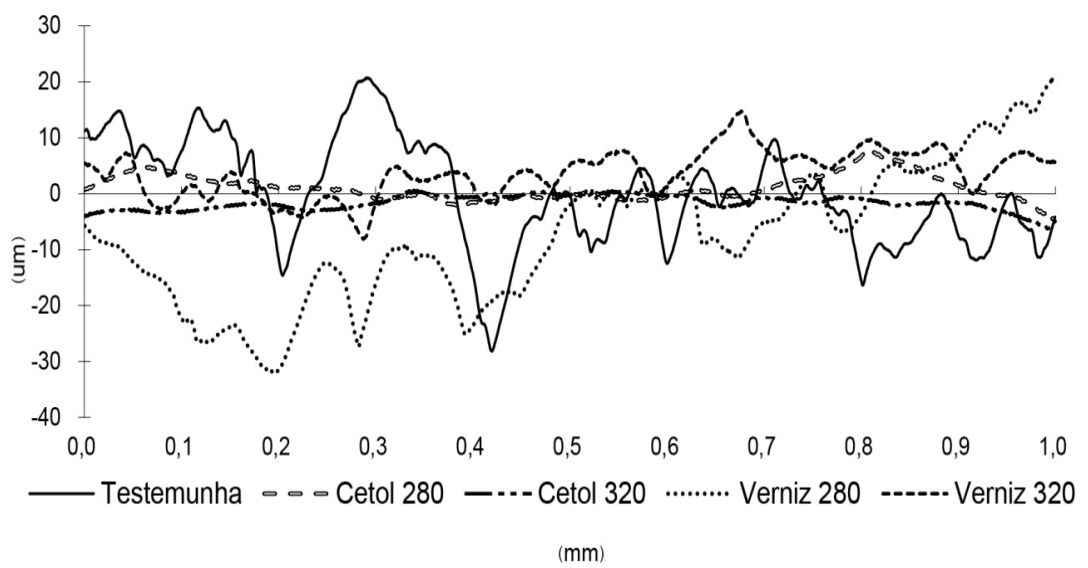

Figure 1: Roughness profile of untreated marupa wood and wood treated with 3 coats of varnish and cetol and with 280 and 320-grit sandpaper.

A clear reduction tendency of the peaks and valleys in the roughness of the samples treated with cetol and sanding is possible to be observed in Figure 1 in relation to the control and the other treatments with varnish. These values characterize this surface as being less rough, and consequently of better quality (Raabe et al. 2017) when compared to the samples of the other treatments. The peaks and valleys of these profiles generally showed lower variation in depth and height, showing an evolution in roughness reduction by the sanding process followed by cetol application.

On the other hand, a slight reduction in the value of the peaks and valleys is observed in Figure 1 by analyzing the roughness profiles of the slides after applying varnish, and presenting similar values to the control. Sanding with 320-grit sandpaper made the peaks and valleys smaller, leaving the surface smoother.

Raabe et al. (2017) cited Richter et al. (1995) in mentioning that the success of surface finishings such as paint, varnish, etc. applied with the aim of protecting, improving and increasing the economic value of the final product is closely linked to the wood surface smoothness. Therefore, the smoothness of the surface is very important for using lesser amounts of surface finishing materials (Aslan et al. 2008).

\section{CONCLUSIONS}

Marupa wood darkened after applying cetol and varnish;

Cetol darkened the wood the most, mainly after applying 3 coats;

Sanding did not significantly modify the wood's colour;

Two coats of finishing product were sufficient to reduce the roughness, with the cetol being more efficient than the varnish;

The sandpaper grit used did not matter in reducing the roughness by applying the cetol.

The research suggests that 280-grit sandpaper is enough to obtain smoother surfaces with the two finishing products studied. Applying a two-coat finish of the products used was also sufficient to obtain a satisfactory finish. The wood species being used should also be considered for these recommendations.

Although the 280 and 320-grit sandpaper and two and three coats of the finishing products showed no 
differences, in practice the samples were smoother and better finished with 320-grit and three coatings.

\section{REFERENCES}

Almeida, A.A.C.; Moreira, S.J.R.; Alves, B.J.R.; Cabral, M.J. 2016. Utilização da técnica sunset laser para distinguir superfícies usinadas de madeira com qualidades similares. Cerne 22 (2): 159-162. http://dx.doi. org/10.1590/01047760201622022025.

ASTM D1666-87. 1995. Standard method for conducting machining tests of wood and wood base materials (reapproved 1994). Philaldelphia. 226 - 245.

ASTM D2244. 2009. Standard Practice for Calculation of Colour Tolerances and Colour Differences from Instrumentally Measured Colour Coordinates. West Conshohocken, PA, USA.

Arruda, L.M.; Gonçalez, J.C.; Del Menezzi, C.H.S.; Melo, R.R. 2011. Estudo preliminar das propriedades de compensados produzidos com lâminas de paricá (Schizolobium amazonicum Huber ex Ducke) modificadas termomecanicamente. Ciência da Madeira 2(1): 29-42. https://doi.org/10.15210/cmad.v3i2.4044.

Aslan, S.; Cos-Kun, H.; Kilic, M. 2008. The effect of the cutting direction, number of blades and grain size of the abrasives on surface roughness of Taurus cedar (Cedrus libani A. Rich.) woods. Building and Environment 43(5): 696-701. https://doi.org/10.1016/j.buildenv.2007.01.048.

Aydin, I.; Demirkir, C.; Colak, S.; Salca, E. 2013. The effect of veneers roughness on bonding and some mechanical properties of plywood. Pro Ligno 9 (1): 41-49.

Camargos, J.A.; Gonçalez, J.C. 2001. A colorimetria aplicada como instrumento na elaboração de uma tabela de cores de madeira. Brasil Florestal (71): 30-41.

Cavalcante, L.C. 2006. Avaliação de novas espécies madeireiras na fabricação do cajón. Monografia, Universidade de Brasília, Brasília, Brasil.

Cisneros, A.; Nisgoski, S.; Moglia, J. G.; Córdoba, M. 2019. Colorimetría en la madera de Prosopis alba. Maderas-Cienc Tecnol 21(3): 393-404. http://dx.doi.org/10.4067/S0718-221X2019005000311.

Costa, M.A. 2009. Avaliação de metodologias alternativas para caracterização do ataque de fungos apodrecedores de madeiras. Mestrado em Ciências Florestais, Departamento de Engenharia Florestal, Universidade de Brasília, Brasília, Brasília, Brasil.

De Meijer, M.; Thurich, K.; Militz, H. 1998. Comparative study on penetration characteristics of modem wood coatings. Wood Sci Technol 32(5):347-365. https://doi.org/10.1007/BF00702791.

Freitas, A.; Gonçalez, J.C.; Menezzi, D.; Henrique, C. 2016. Thermomechanical treatment and the effects on the properties of Simarouba amara (Aubl.). Floresta e Ambiente 23(4): 565-572. https://doi. org/10.1590/2179-8087.144115.

Gonçalez, J.C. 1993. Caracterisation technologique de quatre espéces peu connues da la forêt Amazonienne: anatomie, chimie, couleur, propriétés physiques et mécaniques. Nancy, 1993. 446f.: il. Thèse (Doctorat) - Ecole Nationale du Génie Rural des Eaux et des Forêts, Nancy.

Gonçalez, J.C.; Félix, T.L.F.; Gouveia, F.N.; Camargos, J.A.A.; Ribeiro, P.G. 2010. Efeito da radiação ultravioleta na cor da madeira de freijó (Cordia goeldiana Huber) após receber produtos de acabamentos. Ciência Florestal 20 (4): 657-664. https://doi.org/10.5902/198050982424.

Hazir, E.; Koc, K.H. 2018. A modeling study to evaluate the quality of wood surface. Maderas- Cienc Tecnol 20 (4): 691-702. https://doi.org/10.4067/S0718-221X2018005041501.

Hikita,Y.; Toyoda, T.; Azuma, M. 2001. Weathering testing of timber: discoloration. In: Imamura, Y 
(Ed.). High performance utilization of wood for outdooor uses. Press-Net, 27-32. Kyoto, Japan.

Hiziroglu, S.; Zhong, Z.W.; Ong, W.K. 2014. Evaluating of bonding strength of pine, oak and nyatoh wood species related to their surface roughness. Measurement 49: 397-400. https://doi.org/10.1016/j.measurement.2013.11.053.

Imirzi, H.O.; Ülker, O.; Burdurlu, E. 2014. Effect of densification temperature and some surfacing techniques on the surface roughness of densified Scots Pine (Pinus sylvestris L.). BioResources 9(1): 191-209. Ivalsa.

Jakub, S.; Martino, N. 2015. Wood surface roughness-what is it?. Trees and timber research institute:

JIS. 2001. Geometrical Products Specifications (GPS) - Surface texture: profile method - Terms, definitions and surfaces texture parameters. JIS B 0601-2001. Tokyo.

Kerber, P.R.; Stangerlin, D.M.; Pariz, E.; de Melo, R.R.; de Souza, A.P.; Calegari, L. 2016. Colorimetry and surface roughness of three amazon woods submitted to natural weathering. Nativa: Pesquisas Agrárias e Ambientais 4(5): 303-330.

Kilic, M.; Hiziroglu, S.; Burdurlu, E. 2006. Effect of machining on surface roughness of wood. Building and Environment 41(8):1074-1078. https://doi.org/10.1016/j.buildenv.2005.05.008.

Koch, P. 1964. Wood machining processes. Ronald Press Co: New York.

Laina, R.; Sanz-Lobera, A.; Villasante, A.; López-Espí, P.; Martínez-Rojas, J.A.; Alpuente, J.; Sánchez-Montero, R.; Vignote, S. 2017. Effect of the anatomical structure, wood properties and machining conditions on surface roughness of wood. Maderas-Cienc Tecnol 19(2): 203-212. https://doi.org/10.4067/S0718221X2017005000018.

Melo, R.R.; Del Menezzi, C.H.S.; Souza, M.R.; Stangerlin, D.M. 2013. Avaliação das propriedades físicas, químicas, mecânicas e de superfície de lâminas de paricá (Schizolobium amazonicum Huber ex. Ducke). Floresta Ambiente 20(2): 238-249. https://doi.org/10.4322/floram.2013.004.

Mendes, T.J.; Gonçalez, J.C.; Teles, R.F.; Lima, C.M. 2016. Effect of artificial weathering on wood laminates colour treated with two finishing products. Cerne 22(1): 101-110. https://doi.org/10.1590/0104776 0201622011911.

Mesquita, R.R.; Gonçalez, J.C.; de Paula, M.H. 2017. Comportamento da madeira de Tectona grandis frente ao intemperismo. Florestal 47(1): 29-36. https://doi.org/10.5380/rf.v47i1.38562.

Mori, L.S.O.; Mori Akira, F.; Lima, T.J.; Trugilho, P.F.; Oliveira, C.A. 2004. Características tecnológicas na cor da madeira de eucaliptos. Ciência Florestal 14 (2): 123-132.

Moura de, L.F.; Hernandez, R.E. 2006. Evaluation of varnish coating performance for three surfacing methods on sugar maple wood. Forest Prod J 56 (11/12): 130-136.

Raabe, J.; Del Menezzi, C.; Gonçalez, J. 2017. Avaliação da Superfície de Lâminas Decorativas de Curupixá (Micropholis venulosa Mart. Eichler). Floresta e Ambiente 24. e20150054. https://doi.org/10.1590/21798087.005415.

Richter, K.; Feist, W.; Kanebe, M. 1995. The effects of surface roughness on the performance of finishes. For Prod J 7-8(45): 91-97.

Souza, M.H.; Magliano, M.M.; Camargos, J.A.A. 1997. Madeiras Tropicais Brasileiras. IBAMA/Laboratório de Produtos: Florestais, Brasília, Brasil.

Williams, D.; Morris, R. 1998. Machining and related mechanical properties of $15 \mathrm{BC}$ wood species. Special Publication Forintek Canada Corp.Vancouver, Canada. 